\title{
THE FIRST HOSPITAL-BASED REGISTRY OF PATIENTS WITH MULTIPLE SCLEROSIS IN CROATIA
}

\author{
Vanja Bašić Kes, Marijana Lisak, Miljenka Jurašić, Iris Zavoreo, Ana Dimitrović, \\ Ivana Kobasić and Lucija Zadro Matovina
}

Clinical Department of Neurology, Sestre milosrdnice University Hospital Centre, Reference Center for Neuroimmunology and Neurogenetics, Reference Center for Neurovascular Disorders, Reference Center for Headaches, Reference Center for Diagnosis and Treatment of Acute and Chronic Pain, Ministry of Health of the Republic of Croatia, Zagreb, Croatia

SUMMARY - The first hospital-based registry of patients with multiple sclerosis (MS) was established at the University Department of Neurology, Sestre milosrdnice University Hospital Centre, Zagreb, Croatia, in 2014. The aim of the registry was to continuously provide data on the number of hospital-managed MS patients, patterns of disease progression, predictors of disability progression, changes in lifespan and long-term outcomes. Relevant medical data included age and gender of MS patients, family history of MS, data on previous immunization, disease course, Expanded Disability Status Scale (EDSS) score, cerebral magnetic resonance imaging (MRI) lesion load quantification, and cerebrospinal fluid analysis. Lifestyle habits in MS patients including smoking and alcohol consumption were also analyzed. All data were obtained from primary medical records between January 1, 2014 and January 1, 2015, and entered into the database. Data were evaluated retrospectively according to age and gender differences. Results showed that the majority of patients enrolled in the registry had the remitting relapsing course of disease, with low EDSS score indicating no disability or minimal disability. Cerebrospinal fluid analysis showed that oligoclonal bands were present in the majority of MS patients, with affected blood-brain-barrier permeability. According to the remitting relapsing course of the disease, cerebral MRI quantitative analysis demonstrated a significant lesion load in the majority of patients. When stratified by lifestyle habits, smokers and alcohol consumers were more prevalent among male patients. Our hospital-based registry might be considered as a prototype for the national MS registry and should be improved for reliable statistical analysis.

Key words: Multiple sclerosis; Registries; Medical records; Disease progression; Croatia

\section{Introduction}

Multiple sclerosis (MS) is characterized by heterogeneous clinical expression, an unpredictable course, and a variable prognosis. The etiology of MS is still unknown, but it is widely accepted that it is an immune mediated demyelinating process, precipitated by

Correspondence to: Marijana Lisak, $M D, P h D$, Clinical Department of Neurology, Sestre milosrdnice University Hospital Centre, Vinogradska c. 29, HR-10000 Zagreb, Croatia

E-mail:marijana.lisak@kbcsm.hr; marijanalisak@gmail.com

Received November 23, 2016, accepted May 29, 2017 unknown environmental factors, in genetically susceptible people. MS affects an estimated 2-2.5 million people worldwide, of whom approximately 630000 are in Europe ${ }^{1,2}$. The incidence of MS is about 7 cases per 100000 persons per year. The prevalence rate varies between races and geographical latitudes, ranging from 50 to 120 per 100, with the highest prevalence observed in northern European countries ${ }^{1-3}$. Currently, there are no statistical reports on MS patients in Croatia. There is not even an estimated number of MS, or data on the prevalence of MS disease patterns in Croatia. There is still a significant lack of the information 
required to improve health service for MS patients. Details on how MS impacts their everyday lives are also unknown. The establishment of MS patient registries addresses some of deficient MS data and provides an insight into the potential causative and risk factors in MS. Also, patient registries offer data with respect to disease progression, predictors of disability progression and changes in lifespan, and improve long-term outcomes. Epidemiological data help in creating better MS outcome; thus, in 2014, we established the hospital-based registry of MS patients at the Clinical Department of Neurology, Sestre milosrdnice University Hospital Centre in Zagreb, as the first one in Croatia. We aimed to capture the number of hospital managed MS patients, relevant medical records, and lifestyle habits, with intention to expand the MS registry at the national level in the future. Primary objectives of this MS registry were as follows: to adapt the functional clinical system within specialist clinical centers with identifiable data to the register; to build an anonymous register of MS patients; to build suitable analytical tools for use of the register; and to expand it at the national level. A multi-faceted approach was accepted, combining technical developments, security measures, and quantitative and qualitative methodologies with participatory design. The information collected in this registry provides enough evidence to launch the national Croatian registry, with more MS clinical centers joining in the future.

\section{Subjects and Methods}

Hospital-based MS registry formed at the Clinical Department of Neurology, Sestre milosrdnice University Hospital Centre, tracked medical records of a total of 240 MS patients. To be eligible, patients should have experienced the first symptom suggestive of MS between January 1, 2014 and January 1, 2015. To be finally included as MS cases, patients had to meet the revised $2010 \mathrm{McD}$ onald criteria for $\mathrm{MS}^{4}$. The main source of case identification were hospital medical files, with relevant medical data routinely collected by neurologists at the Neuroimmunology and Neurogenetics Unit, Clinical Department of Neurology, Sestre milosrdnice University Hospital Centre in Zagreb, Croatia, during hospitalization. Relevant registry data included the following: age and gender; family history of MS; data on previous immunization: vaccination for morbillivirus (measles virus), parotitis virus (mumps) and rubella virus, hepatitis $B$ virus (HBV), and other nonspecific vaccination; MS disease course (primary progressive MS (PPMS), remitting relapsing MS (RRMS), or secondary progressive MS (SPMS); Expanded Disability Status Scale (EDSS) score; cerebral magnetic resonance imaging (MRI) T2/FLAIR lesion load quantification: moderate lesion load (0-9), significant lesion load (10-20) and progressive lesion load (more than 20); cerebrospinal fluid (CSF) examination: protein index for evaluation of intrathecal $\mathrm{IgG}$ synthesis, evaluation of the blood-brain-barrier permeability, presence of oligoclonal bands (OCBs); evaluation of polyspecific, intrathecal humoral immune response against viral agents including antibodies to measles, rubella and varicella zoster virus (MRZ) reaction (MRZR); and further CSF analysis for Borrelia burgdorferi, neurotropic viruses, and central nervous system (CNS) parasites. Lifestyle habits, smoking and alcohol consumption were also analyzed. All data obtained from medical records were examined and entered into the database.

Descriptive statistics was used to describe the basic data characteristics. Quantitative analysis was performed to provide summaries of the sample and measures.

\section{Results}

Analysis of the hospital-based registry included 240 MS patients admitted to the Clinical Department of Neurology, Sestre milosrdnice University Hospital Centre between January 1, 2014 and January 1, 2015. There were 55 (22.92\%) male and 185 (77.08\%) female patients, mean age 34.4 (range 18-65) years. In the total group of patients, family history of MS was positive in $3.7 \%$ of male $v s .1 .61 \%$ of female patients. Stratification according to MS disease subtypes showed that PPMS was present in $6.38 \%$ of male and none of female patients; RRMS in $89.36 \%$ of male vs. $92.13 \%$ of female patients; and SPMS in $4.26 \%$ of male vs. 7.09\% of female patients. Functional disability stratification showed the mean EDSS score of 1.81 in male vs. 1.79 in female patients. Cerebral MRI T2/ FLAIR CNS lesion load quantification showed that $31.58 \%$ of male vs. $37.82 \%$ of female patients had 0-9 lesions; $52.63 \%$ of male vs. $53.21 \%$ of female patients 
10-20 lesions; and $15.79 \%$ of male vs. $8.97 \%$ of female patients more than 20 lesions. CSF protein index finding was positive in $17.86 \%$ of male vs. $5.88 \%$ of female patients. Blood-brain-barrier permeability was affected in $70.37 \%$ of male vs. $50 \%$ of female patients. OCBs were present in $90 \%$ of male $v$ s. $88.96 \%$ of female patients. MRZR was negative in all patients. CSF analysis for Borrelia burgdorferi, neurotropic viruses and CNS parasites was negative in $91.8 \%$ of male vs. 98.08\% of female patients. Data on previous immunization showed that $87.18 \%$ of male vs. $75.53 \%$ of female patients were immunized. HBV vaccination was positive in $30 \%$ of male $v s .35 .19 \%$ of female patients. Other nonspecific vaccination was positive in $10.53 \%$ of male patients and negative in female patients. When stratified by lifestyle habits, there were $33.85 \%$ of smokers among male vs. $21.8 \%$ of female patients. There were $15.63 \%$ of alcohol consumers among male vs. $5.29 \%$ of female patients.

Stratification according to gender and age (0-18, $18-45,45-55,55-65$ and $>65$ age groups) showed age group differences in the group of male patients.

In the group of male MS patients aged 1-18 years, there were 3 patients (mean age, 17 years). Family history of MS was positive in 50\% of patients. According to MS form, RRMS was present in all patients, with the mean EDSS score 1. Cerebral MRI T2/FLAIR lesion load quantification showed that $66.67 \%$ of $\mathrm{pa}^{-}$ tients had 10-20 lesions and 33.33\% had more than 20 lesions. CSF protein index finding was positive in 50\% and the blood-brain-barrier permeability was affected in all patients. OCBs were present in all patients, while MRZR and CSF analysis for Borrelia burgdorferi, neurotropic viruses and CNS parasites were negative in all patients. Data on previous immunization showed that all patients were immunized. HBV vaccination was negative and nonspecific vaccination positive in all patients. When stratified by lifestyle habits, there were no smokers or alcohol consumers in this subgroup.

In the subgroup of male MS patients aged 18-45 years, there were 41 patients (mean age, 29.2 years). Family history of MS was positive in $3.23 \%$ of patients. According to MS form, PPMS was present in $6.45 \%$, RRMS in $90.32 \%$ and SPMS in $3.23 \%$ of patients. The mean EDSS score was 1.73. Cerebral MRI T2/FLAIR lesion load quantification showed that $31.43 \%$ of patients had 0-9 lesions, $57.14 \%$ had $10-20$ lesions, and $11.43 \%$ had more than 20 lesions. CSF protein index was positive in $14.29 \%$ and the bloodbrain-barrier permeability was affected in $74.29 \%$ of patients. OCBs were present in $93.55 \%$ of patients, while MRZR and CSF analysis for Borrelia burgdorferi, neurotropic viruses and CNS parasites were negative in all patients. Data on previous immunization showed that $91.67 \%$ of patients were immunized. HBV vaccination was positive in $45.45 \%$ of patients, while nonspecific vaccination was negative in all patients. When stratified by lifestyle habits, there were $36.84 \%$ of smokers and $16.22 \%$ of alcohol consumers in this subgroup.

In the subgroup of male MS patients aged 45-55 years, there were 8 patients (mean age, 49.5 years). Family history of MS was negative in all patients. According to MS form, all patients had RRMS form. The mean EDSS score was 2.19. Cerebral MRIT2/FLAIR lesion load quantification showed that $37.5 \%$ of $\mathrm{pa}^{-}$ tients had 0-9 lesions, $37.5 \%$ had 10-20 lesions, and $25 \%$ had more than 20 lesions. CSF protein index finding was positive in $33.33 \%$ and the blood-brainbarrier permeability was affected in $83.33 \%$ of patients. OCBs were present in all patients, while MRZR and CSF analysis for Borrelia burgdorferi, neurotropic viruses and CNS parasites were negative in all patients. Data on previous immunization showed that all patients were immunized. HBV vaccination was positive in $25 \%$ of patients, while nonspecific vaccination was negative in all patients. When stratified by lifestyle habits, there were $25 \%$ of smokers and $12.5 \%$ of alcohol consumers in this subgroup.

In the subgroup of male MS patients aged 55-65 years, there were 2 patients (mean age, 56.5 years). Family history of MS was negative in all patients. According to MS form, all patients had RRMS form. The mean EDSS score was 1. Cerebral MRI T2/FLAIR lesion load quantification showed that all patients had 10-20 lesions. CSF protein index finding was negative and the blood-brain-barrier permeability affected in all patients. OCBs were not present, and MRZR as well as CSF analysis for Borrelia burgdorferi, neurotropic viruses and CNS parasites were negative in all patients. Data on previous immunization showed that all patients were immunized. HBV vaccination and nonspecific vaccination was negative in all patients. When stratified by lifestyle habits, there were no smokers or alcohol consumers in this subgroup. 
In the subgroup of male MS patients older than 65 years, there was 1 patient. Family history of MS was negative. According to MS form, the patient had RRMS. The mean EDSS score was 1. Cerebral MRI T2/FLAIR lesion load quantification showed that the patient had 0-9 lesions. CSF protein index finding was negative, and the blood-brain-barrier permeability was affected. OCBs were present, and MRZR as well as CSF analysis for Borrelia burgdorferi, neurotropic viruses and CNS parasites were negative. Data on previous immunization were positive, while $\mathrm{HBV}$ vaccination and nonspecific vaccination was negative. The patient was a smoker and alcohol consumer.

Stratification according to gender and age (0-18, $18-45,45-55,55-65$ and $>65$ age groups) showed age group differences in the group of female patients.

In the subgroup of female MS patients aged 0-18 years, there were 8 patients (mean age, 17.5 years). Family history of MS was negative in all patients. According to MS form, RRMS was present in 83.33\% and SPMS in $16.67 \%$ of patients. The mean EDSS score was 1.1. Cerebral MRI T2/FLAIR lesion load quantification showed that $83.33 \%$ of patients had $10-$ 20 lesions and $16.67 \%$ had more than 20 lesions. CSF protein index was negative and the blood-brain-barrier permeability affected in all patients. OCBs were present in all patients, while MRZR and CSF analysis for Borrelia burgdorferi, neurotropic viruses and CNS parasites were negative in all patients. Data on previous immunization showed that $40 \%$ of patients were immunized. $\mathrm{HBV}$ vaccination was positive in $66.67 \%$ of patients, while nonspecific vaccination was negative in all patients. When stratified by lifestyle habits, there were $12.5 \%$ of smokers and no alcohol consumers in this subgroup.

In the subgroup of female MS patients aged 18-45 years, there were 149 patients (mean age, 32.7 years). Family history of MS was positive in $1.56 \%$ of patients. According to MS form, RRMS was present in $92.22 \%$ and SPMS in $6.67 \%$ of patients, while the benign course was detected in $1.11 \%$ of patients. The mean EDSS score was 1.82. Cerebral MRIT2/FLAIR lesion load quantification showed that $44.44 \%$ of patients had 0-9 lesions, $45.37 \%$ had $10-20$ lesions, and $10.19 \%$ had more than 20 lesions. CSF protein index finding was positive in $4.63 \%$ and the blood-brainbarrier permeability affected in $54.08 \%$ of patients. OCBs were present in $93.52 \%$ of patients, and MRZR was negative in all patients. Serology for Borrelia burgdorferi and neurotropic viruses was positive in $10.42 \%$ and serology for CNS parasites was positive in $2.44 \%$ of patients. Data on previous immunization showed that $79.41 \%$ of patients were immunized. HBV vaccination was positive in $36.11 \%$ of patients, while nonspecific vaccination was negative in all patients. When stratified by lifestyle habits, there were $20.98 \%$ of smokers and $5.63 \%$ of alcohol consumers in this subgroup.

In the subgroup of female MS patients aged 45-55 years, there were 25 patients (mean age, 50.4 years). Family history of MS was positive in $5.26 \%$ of patients. According to MS form, all patients had RRMS. The mean EDSS score was 1.53. Cerebral MRI T2/ FLAIR lesion load quantification showed that $22.73 \%$ of patients had 0-9 lesions and 77.27\% had 10-20 lesions. CSF protein index finding was positive in $6.25 \%$ and the blood-brain-barrier permeability was affected in $52.94 \%$ of patients. OCBs were present in $75 \%$ of patients, while MRZR was negative in all patients. CSF analysis for Borrelia burgdorferi, neurotropic viruses and CNS parasites was negative in all patients. Data on previous immunization showed that $66.67 \%$ of patients were immunized. HBV vaccination and nonspecific vaccination was negative in all patients. When stratified by lifestyle habits, there were $12.5 \%$ of smokers and $4.7 \%$ of alcohol consumers in this subgroup.

In the subgroup of female MS patients aged 55-65 years, there were 4 patients (mean age, 59.5 years). Family history of MS was negative in all patients. According to MS form, all patients had RRMS. The mean EDSS score was 1. Cerebral MRI T2/FLAIR lesion load quantification showed that $50 \%$ of patients had 0-9 lesions and 50\% had more than 20 lesions. CSF protein index finding was negative in all patients, and the blood-brain-barrier permeability was affected in $25 \%$ of patients. OCBs were present in all patients, while MRZR, as well as serology for Borrelia burgdorferi, neurotropic viruses and CNS parasites were negative in all patients. Data on previous immunization, $\mathrm{HBV}$ vaccination and nonspecific vaccination were negative in all patients. When stratified by lifestyle habits, there were $75 \%$ of smokers and no alcohol consumers in this subgroup.

In the subgroup of female MS patients older than 65 years, there were 3 patients (mean age, 61.4 years). 
Family history of MS was negative in all patients. According to MS form, all patients had RRMS. The mean EDSS score was 2. Cerebral MRI T2/FLAIR lesion load quantification showed that all patients had 10-20 lesions. CSF protein index finding was negative in all patients, and the blood-brain-barrier permeability was affected in $66.67 \%$ of patients. OCBs were present in all patients, while MRZR and serology for Borrelia burgdorferi, neurotropic viruses and CNS parasites were negative in all patients. Data on previous immunization, HBV vaccination and nonspecific vaccination were negative in all patients. There were $33.33 \%$ of smokers and $33.33 \%$ of alcohol consumers in this subgroup.

\section{Discussion}

Multiple sclerosis is the most common chronic neurologic disease in adults between 20 and 50 years of age, with the peak onset in early thirties, which is in accordance with data collected in this registry. Women are generally affected approximately twice as often as men $^{1-3}$. Our hospital registry data demonstrated that women were affected with MS three times as often as men. Positive family history of MS increases the risk of developing the disease. Registry data showed positive family history of MS in $3.7 \%$ of male vs. $1.61 \%$ of female patients. The natural history of MS suggests that there are different patterns of disease course ${ }^{5-8}$. RRMS presentation is observed in the majority of MS patients ( $80 \%-85 \%$ of MS population), which is in accordance with the results of our study, where the remitting relapsing course was present in $89.36 \%$ of male and $92.13 \%$ of female patients.

Approximately 65\%-70\% of RRMS patients experience gradual accumulation of disability and fewer relapses later in the course of disease, which evolves into SPMS characterized by neurodegenerative features. The median time for patients with RRMS to progress into SPMS is about 10 years ${ }^{7,8}$. According to the results of our registry, the SPMS course was present in $4.26 \%$ of male vs. $7.09 \%$ of female patients. PPMS patients experience progression of disability from the onset of disease. Stratification according to MS disease type in our study showed that PPMS was present only in $6.38 \%$ of male patients.

Disability accumulation refers to worsening in EDSS score, either due to incomplete recovery from relapses or occurring independently of relapses, irrespective of the MS course. Functional disability stratification in the total group of patients showed that the mean EDSS score was 1.81 in male and 1.79 in female patients, referring to the range of no disability or minimal disability according to functional scores, possibly due to appropriate treatment of patients.

A patient with the relapsing course but no relapses, and new or unequivocally enlarging $\mathrm{T} 2$ lesions during the assessment period could be considered inactive, as well as a patient with PPMS with no acute attacks and no MRI activity ${ }^{9,10}$. Cerebral MRI T2/FLAIR lesion load analysis showed that $31.58 \%$ of male vs. $37.82 \%$ of female patients had moderate (0-9 lesions) lesion load; $52.63 \%$ vs. 53.21\% had significant (10-20) lesion load; and $15.79 \%$ vs. $8.97 \%$ had progressive (more than 20) lesion load. In the majority of patients, MRI quantification verified significant lesion load, which was in accordance with the prevalent RRMS course of the disease.

Cerebrospinal fluid $\mathrm{IgG}$ levels or $\mathrm{IgG}$ index are consistently elevated in MS, due to increased intrathecal IgG synthesis, resulting in abnormal OCBs. Detection of OCBs has been established as the most useful CSF marker to aid in the diagnosis of $\mathrm{MS}^{11}$. In our study, CSF protein index finding was positive in $17.86 \%$ of male vs. $5.88 \%$ of female patients. Bloodbrain-barrier permeability was affected in $70.37 \%$ of male vs. $50 \%$ of female patients, and OCBs were present in $90 \%$ of male $v s .88 .96 \%$ of female patients. The majority of patients with MS display MRZR. However, a positive MRZR can also be found in patients with CNS vasculitis, raising the question whether it is a high specificity marker of MS or nonspecific marker of CNS autoimmunity. In our study, MRZR was negative in all female and male patients. Further investigations of MRZR in rare autoimmune conditions, which were not available for analysis in this study, are reasonable to refine further the specificity of this parameter. A variety of neurotropic viruses have been linked to MS. Data on previous immunization including measles and rubella virus showed that $87.18 \%$ of male and $75.53 \%$ of female patients were immunized. HBV vaccination was positive in $30 \%$ of male and $35.19 \%$ of female patients. Other nonspecific vaccination was positive in $10.53 \%$ of male patients and negative in all female patients. In our group of patients, serology data on Borrelia burgdorferi and neurotropic viruses, and se- 
rology data on CNS parasites were negative in 100\% of male and $98.08 \%$ of female patients.

There is strong evidence from meta-analysis and case-control studies that smoking is associated with $\mathrm{MS}^{12-16}$. Although self-reported smoking status can be reliable, the accuracy of this measure is reduced in lower socioeconomic groups, younger ages, and in some ethnic groups. When stratified by lifestyle habits, in our group of patients there were $33.85 \%$ of male smokers vs. $21.8 \%$ of female smokers. Possible alcohol abuse and drug misuse were associated with younger age, less severe MS related disability and being employed, as well as greater self-reported depressive symptoms ${ }^{17}$. In our study, there were $15.63 \%$ of male vs. $5.29 \%$ of female alcohol consumers.

There were several significant limitations of this study. Some data were not carefully monitored and were found unreliable, thus being excluded from the analysis. These were current treatments and long-term outcomes. We plan to improve this registry by expanding it to the national MS patient database and collecting relevant laboratory data, adverse events and comorbidity according to MS subtypes. A multi-faceted approach was accepted but not used correctly by the staff, thus limiting data collection. Quantitative and qualitative methodologies for relevant statistical analysis were ongoing during presentation of study results, thus reliable statistical analysis was not possible.

\section{Conclusion}

In conclusion, the results of our study showed that the majority of MS patients recorded in the Clinical Department of Neurology hospital-based registry were young adults, in early thirties, with the prevalent remitting relapsing course of the disease. Functional disability stratification of the total group of patients showed low EDSS score, referring to the range of no disability or minimal disability. Cerebral MRI quantification verified significant lesion load in the majority of patients, in accordance with the prevalent RRMS course of the disease. Blood-brain-barrier permeability was affected in the majority of patients, both male and female, with positive OCBs. In our study, MRZR was negative in all patients, further refining the specificity of this parameter. Data on previous immunization showed that the majority of patients, both male and female, had been immunized previously. When strati- fied by lifestyle habits, in the total group of patients, smokers were prevalent among male patients, and there were three times more alcohol consumers in the group of male as compared with female patients. Accordingly, the hospital based MS registry established at the Clinical Department of Neurology, Sestre milosrdnice University Hospital Centre should be improved to provide all necessary data for a reliable statistical analysis. However, this registry could be considered as a prototype for the national Croatian MS registry, with more clinical hospital centers joining in the future. There is a potential, beyond this study, that the information provided in the MS registry could be inserted into clinical records, thereby directly influencing the care that MS patients receive.

\section{References}

1. Milo R, Kahana E. Multiple sclerosis: geoepidemiology, genetics and the environment. Autoimmun Rev. 2010;9(5):A387-94. doi:10.1016/j.autrev.2009.11.010. Epub 2009 Nov 20

2. Thompson AJ, Rompani P, Dua T, et al. WHO/MSIF: Atlas of MS: multiple sclerosis resources across the world. Mult Scler. 2008;S153.

3. Compston A, Coles A. Multiple sclerosis. Lancet. 2002;359: 1221-31.

4. Polman CH, Reingold SC, Banwell B, et al. Diagnostic criteria for multiple sclerosis: 2010 revisions to the McDonald criteria. Ann Neurol. 2011;69(2):292-302. doi: 10.1002/ana.22366

5. Confavreux C, Vukusic S. The clinical course of multiple sclerosis. Handb Clin Neurol. 2014;122:343-69. doi: 10.1016/ B978-0-444-52001-2.00014-5

6. Compston A, Coles A. Multiple sclerosis. Lancet. 2008; 372:1502-18.

7. Lublin FD, Baier M, Cutter G. Effect of relapses on development of residual deficit in multiple sclerosis. Neurology. 2003;61:1528-32.

8. Noseworthy JH, Lucchinetti CF, Rodriguez M, et al. Multiple sclerosis. N Engl J Med. 2000;343:938-52.

9. Debette S, Markus HS. The clinical importance of white matter hyperintensities on brain magnetic resonance imaging: systematic review and meta-analysis. BMJ.2010;1:c3666. doi: 10.1136 /bmj.c3666

10. Launer LJ. Epidemiology of white matter lesions. Top Magn Reson Imgaing. 2004;1:365-7.

11. Kottil WR. Cerebrospinal fluid in multiple sclerosis Ann Indian Acad Neurol. 2009;12(4):246-53. doi: 10.4103/09722327.58282

12. Handel AE, Williamson AJ, Disanto G, Dobson R, Giovannoni G, Ramagopalan SV. Smoking and multiple sclerosis: 
an updated meta-analysis. PLoS One. 2011;6:e16149. doi: 10.1371/journal.pone.0016149

13. Ghadirian P, Dadgostar B, Azani R, Maisonneuve P. A casecontrol study of the association between socio-demographic, lifestyle and medical history factors and multiple sclerosis. Can J Public Health. 2001;92:281-5.

14. Pekmezovic T, Drulovic J, Milenkovic M, Jarebinski M, Stojsavljevic N, Mesaros S, Kisic D, Kostic J. Lifestyle factors and multiple sclerosis: a case-control study in Belgrade. Neuroepidemiology. 2006;27:212-6.
15. Hernan MA, Olek MJ, Ascherio A. Cigarette smoking and incidence of multiple sclerosis. Am J Epidemiol. 2001;154: 69-74.

16. Marrie RA, Cutter G, Tyry T, Campagnolo D, Vollmer T. Smoking status over two years in patients with multiple sclerosis.Neuroepidemiology.2009;32:72-9.doi:10.1159/000170910. Epub 2008 Nov 12

17. Bombardier CH, Ehde DM, Gibbons LE, Moore D, Kraft GH. Alcohol and drug abuse among persons with multiple sclerosis. Mult Scler. 2004;10:35-40.

Sažetak

\title{
PRVI BOLNIČKI REGISTAR BOLESNIKA S MULTIPLOM SKLEROZOM U HRVATSKOJ
}

\author{
V. Bašić Kes, M. Lisak, M. Jurašić, I. Zavoreo, A. Dimitrović, I. Kobasić i L. Zadro Matovina
}

Prvi bolnički registar bolesnika s multiplom sklerozom (MS) u Hrvatskoj uspostavljen je 2014. godine u Klinici za neurologiju, Klinički bolnički centar "Sestre milosrdnice”, Zagreb. Cilj registra je kontinuirano prikupljanje podataka o broju hospitalno obrađenih bolesnika s MS, oblicima bolesti, prediktorima napredovanja onesposobljenosti, životnim navikama i dugoročnim ishodima za bolesnike. Relevantni medicinski podaci u registru MS uključivali su procjenu dobi i spola bolesnika, obiteljsku anamnezu na MS, podatke o prethodnim imunizacijama, tijeku bolesti, procjenu funkcionalne onesposobljenosti, kvantitativni prikaz lezija mozga magnetskom rezonancijom (MRI) i analizu cerebrospinalnog likvora. Nadalje, analizirane su životne navike bolesnika uključujući pušenje i konzumaciju alkohola. Svi podaci iz bolničke medicinske dokumentacije koji su prikupljeni od 1. siječnja 2014. godine do 1. siječnja 2015. godine upisani su u bazu podataka. Retrospektivno smo analizirali podatke prema dobi i spolu. Relevantni rezultati su pokazali da većina registriranih bolesnika ima relapsno remitirajući oblik bolesti s niskim stupnjem funkcionalne onesposobljenosti. Analiza cerebrospinalnog likvora u većine bolesnika pokazala je pozitivne oligoklonske vrpce i poremećenu propusnost krvno-moždane barijere. Kvantitativna MRI analiza mozga pokazala je značajno opterećenje brojem cerebralnih lezija u većine bolesnika, što odgovara relapsno remitirajućem obliku bolesti. Podjela prema životnim navikama pokazala je da je bilo više pušača i konzumenata alkohola u skupini muških bolesnika. Naš bolnički registar može poslužiti kao prototip za uspostavljanje nacionalnog registra MS, ali ga treba poboljšati kako bi se osigurali svi potrebni podaci za pouzdanu statističku analizu podataka.

Ključne riječi: Multipla skleroza; Registri; Medicinska dokumentacija; Bolest, napredovanje; Hrvatska 